\title{
L'ESPAI COM A ESTRUCTURA PURA (INDAGACIONS SOBRE LA CONSTRUCCIÓ DE L'ENTORN)
}

Manuel Ribas i Pieras

A1. La tasca habitual dels arquitectes, urbanistes i paisatgistes és la de manipular l'Entorn; però, cal referir-se a l'Entom o a l'Espai? Són ambdós sinònims?.

Tal com pretén explicar aquesta comunicació, l'espai no és res, només pura relació dels objectes que així li donen entitat: és un mot secundari. Millor serà, per tant, referir-se a composar, a treballar, a manipular l'Entorn.

A2. Els arquitectes, els urbanistes $i$ també els paisatgistes coincideixen en moltes coses perquè tenen en comú un objectiu, i un encàrrec social: l'organització de l'espai i de les funcions.

El resultat és una estructura de relacions, tant objectives com subjectives, tant del món fisic com del món interior. El resultat és sempre una forma sensible. Si se'm permet la comparació amb la coneguda definició de Ploti, diré que aquesta forma sensible és precisannent l'esplendor de l'estructura subjacent.

A3. Aquesta tasca d'expressar estructures mitjançant les formes composades (pels semiòlegs, articulació del significant per extraure'n un significat), es evidentment una tasca de Comunicació. El mảxim nivell assolible en aquesta comunicació que té com a materials expressius els objectes, és justament la comunicació estêtica, el missatge estètic, possible però no probable. És a dir, dificil d'assolir.

El "compositor de l'entorn" treballa "socialment". Aixi és com intenta comunicir als seus contemporànis el seu personal missatge que és el d'organitzar l'espai i les funcions, com acabo de dir.

A4. A la mateixa base d'aquesta particular Comunicació, que té com a mitjans expressius les formes - naturals o creades- del món físic exterior, hi ha hagut però, des de sempre, un problema que és únic però que es por formular amb dues preguntes equivalents

a) Tots els subjectes veuen, senten, recorden de manera idèntica el món físic?; i b) El món fisic existeix independentment de nosaltres, els seus observadors?.

Crec que aquest és un problema clàssic $i$ que cal resoldre postulant afirmativament la solució. Sense postular-ho no podriem ni seguir endavant en la Teoria del Coneixement.

A5. Fins a aquest punt el raonament s'ha ocupat molt preferentment de les sensacions i implicitament dels sentits com a úniques vies per a conèixer el món lísic. P'erò cal mirar endins, ara.

Però molt abans que els físics ens hagin dit - $\mathrm{fa}$ molt poc temps- que en últin terme la matèria no és sinó és observada, els fenomenòlegs ja ens havien dit que la imatge de l'Entorn depèn de l'observador! (Merlenu-Ponty).

Si les sensacions són exclusivament fruit dels sentits, les percepcions venen acolorides per personals "vidres de colors": són els semiments i la memòria (pensem en Proust). Es podria dir que actúen a la manera de metallenguatges individuals $\mathrm{i}$ expliquen la interpretació de cada observador; d'aquesta manera tota la vida de l'observador comparteix la signilicació i 
s'aboca al damunt dels objectes paisatgístics per tal de ser parcialment protagonista de llur expressió i comunicació. És el principi d'intencionalitat que configura la percepcio.

A6. Hem constatat com es produeix la "lectura" de l'Entorn. Cal anar, però, més enllà perquè el compositor d'espais va més lluny i pretén fer el procès inversament. Vol proposar lecsures noves al seu grup social, anant de la lectura a l'escriptura. Proposa espais interiors resolts en el camp de l'Arquitectura, espais exteriors i publics que resol en el camp del Planejament $i$ del Disseny urbanistic, espais litures que es resolen en el camp del Paisatgisme.

Parlem de la resolució de les funcions socialment requerides $\mathbf{i}$ això inclou, també $\mathbf{i}$ no pas la darrera, la funció que hom prodria anomenar d'aportació estètica.

B1. Si hi ha Comunicació es que deu haver-hi una "llengua" pròpia que reculli el sistema expressiu de l'Entorn.

Si hi ha una llengua hom pot vàlidament parlar d'una "Lingïistica de l'Entorn".

B2. Com tota Lingüística tindrà metodològicament una Sintaxi que definirà uns sintagmes. Seran aquelis contenidors standards de signes que abastaran cadascun immensos conjunts d'expressió però sempre amb idèntica funció en el procés d'expressar l'Entorn.

Els sintagmes propis de la llengua de l'Entorn són sempre geomètrics i coincideixen amb Kandisnki en ser linies, punts i superficies sobre un primordial sintagma que és el Territori (com a portador d'expressió pròpia). En cadascun dels quatre sintagmes enunciats s'agrupen - sempre obeïnt a un tipus - molts diversos sistemes de signes. La combinació de sintagmes construeix l'oració, el discurs, és a dir, el Paisatge com a ens expressiu.

B3. La Linguistica de l'Entorn té també, metodològicament parlant, una Semàntica que ens explica la transmissió dels significats o continguts del Paisatge a partir dels seus signes visibles.

Una Semàntica de l'Entorn visible és particularment útil per als compositors de paisatges, siguin paisatgistes, urbanistes o simplement arquitectes. Si els geògrafs i dels naturalistes s'especialitzen en "Ilegir" l'Entorn i amb això s'acompleix llur Ciència, aquells que he anomenat compositors són també especialistes en la lectura no tant cientifica com sensible, per a poder passar, -amb ple conejxement del territori que cal configurar- a l'"escriptura" de noves expressions i nous missatges.

B4. Si bé és impossible contestar lògicament a la qüestió de l'esteticitat (per què ens agrada o no aquest entom?), si que és possible, mitjançant les aportacions metodològiques de la Ciència Linglistica, contestar i explicar com es formulen els missatges paisatgistics.

Sense poder arribar a resoldre el "perquè" i la seva enorme relativitat (que es desprèn de la subjectivitat de cada observador) ens podem acostar però a uns significats elementals o primaris, amb la composició dels quals es munta l'edifici de cada significació-concreta.

És a dir es tracta d'aconseguir un repertori limitat de missafges bàsics que combinants en el cervell de l'observador li aportin el missatge total.

B5. Els trets elementals de significació són les minimes unitats que per sí soles són ja expressives dels seu contingut.

Dit d'una altra manera són continguts minims, elementals. 
No ho són, en canvi, perquè són espistemològics, exteriors a la significació mateixa, els que s'anomenen principis generals de l'expressió paisatgistica (tals com la sinetria o la jerarquia de components) ni les formes-tipus que hom pot assenyalar com a pautes (tals com p.ex. la composició a base de diagonals o de línia de corba dominant).

B6. Els trets fonamentals de significació s'obtenen com en els anàlisis de predicats de la Semèntica moderna. Són sempre accions, és a dir que en el discurs oral-escrit cal expressar-los amb verbs.

Una primera familia d'accions de significació elemental són directes, és a dir que tenen com a referent $i$ referit a elles mateixes.

Es tracta dels parells: dominar-suportar

connectar-dividir-tancar

cobrir-pavimentar.

B7. Altres accions són reflexes, que tenen necessàriament un referent extern a la composició estudiada. Són accions elementals que cal que "rebotin" en el quadre analitzat $i$ com en una metàfora - sense ser, perỏ, cap metåfora-comparin, repeteixin, indiguin, simbolitzin o es moguin a partir sempre d'un referent exterior.

Cl. A cada paisatge aixi analitzat hi podem trobar diverses accions expressades. A voltes, amb una dominant; a voltes sense cap que domini sobre les altres. Hi pot haver també "paisatges buits", sense comunicació interessant o amb comunicació molt escassa, i en aquest cas s'ens mostraran carents de trets de significació.

C2. La segona conclusió, derivada de la gran relativitat dels significats de l'Entom, is afimar que l'espai com a realitat no existeix; és a dir que l'espai és pura estructura, sense materialitat "perse".

Amb tot el que he dit fins aqui, es pot comprendre millor el que jo anunciava al titol d'aquest escrit. 